\title{
Strategi Pemerintah Republik Indonesia dalam Penanganan Masalah Pelintas Batas Indonesia-Timor Leste
}

\author{
Remigius Seran
}

\author{
Universitas Airlangga
}

\begin{abstract}
ABSTRAK
Urgensi untuk menata perbatasan antara Indonesia dan Timor Leste serta para pelintas batas didasari oleh alasan historis yang lebih kompleks dibandingkan dengan penataan perbatasan Indonesia dengan negara lain. Kebijakan tata kelola perbatasan cenderung mengabaikan variabel identitas kultural, yang kemudian mendorong penggunaan identitas kultural untuk menantang konsepsi dan kebijakan dominan versi negara dalam tata kelola perbatasan. Hal ini ditunjukkan dengan fenomena "jalan tikus" dan jaringan interaksi lintas batas lain yang disebut illegal oleh negara. Untuk mengatasi permasalahan tersebut, penulis mengusulkan ide tata kelola perbatasan yang terintegrasi. Penulis merujuk pada tulisan Brunet-Jailly (2005) yang menempatkan empat dimensi kebijakan secara sejajar. Dapat dipahami bahwa pendekatan budaya dalam kebijakan tata kelola perbatasan menjadi prinsip yang menjiwai kebijakan keamanan, kebijakan politik, dan kebijakan ekonomi dalam tata kelola perbatasan. Konsekuensi praktis dari kajian ini adalah bahwa tata kelola perbatasan harus keluar dari dominasi pendekatan keamanan ekonomi ke pendekatan terintegrasi.
\end{abstract}

Kata kunci: Tata kelola perbatasan, Indonesia-Timor Leste, Pelintas batas budaya.

The urgency to organize borders between Indonesia and Timor-Leste and the border crossers is based on more complex historical reasons compared to the arrangement of Indonesian borders with other countries. The management of borders usually ignores the cultural identity variable, which supports the use of cultural identity to challenge the country's dominant concept and policy in border management. This is proven by the phenomenon of "jalan tikus" and cross-border interaction network that is considered to be illegal by the country. Author proposes integrated border management, in which the cultural approach become one of the main components that would support the other components. In doing so, the author refers to the writings of BrunetJailly (2005), which placed four dimensions of policy in parallel. It can be understood that the cultural approach in border management has become the main principle in security, political, and economy policy in border management. As consequences, border management must come out of the domination of economic security to an integrated approach.

Key Words: Border governance, Indonesia - Timor-Leste, Cultural crosser borders. 


\section{Pendahuluan}

Migrasi sebagai bentuk perpindahan manusia (people on the move) merupakan fenomena yang selalu terjadi di setiap periode kehidupan manusia yang bergerak dan melakukan perpindahan dari satu tempat ke tempat lain (Held 1999). Tidak ada pembatasan, baik pada jarak perpindahan maupun sifatnya, yaitu apakah tindakan itu bersifat suka rela atau terpaksa, serta tidak ada perbedaan antara migrasi ke dalam ataupun ke luar suatu negara. Proses migrasi terjadi sebagai jawaban atas adanya perbedaan antar tempat yang menyangkut faktor-faktor ekonomi, sosial budaya dan lingkungan baik pada tataran individu maupun masyarakat (Taylor 1924). Dalam konteks yang lebih sempit, migrasi berkaitan dengan persoalan pelintas batas yang sering terjadi antara dua negara atau lebih, khususnya bagi mereka yang hidup dan tinggal di wilayah perbatasan. Persoalan ini menjadi kompleks dan rumit ketika para pelintas batas ini tidak dilengkapi dokumen resmi sehingga dianggap sebagai pelintas batas ilegal (illegal crosser border). Fenomena pelintas batas illegal ini merupakan salah satu masalah yang sering dijumpai di Indonesia, khususnya di wilayah perbatasan Indonesia dengan negara-negara tetangga. Di wilayah Timor yang merupakan perbatasan antara Indonesia dengan negara Republik Demokrasi Timor Leste (RDTL), fenomena pelintas batas ilegal menjadi salah satu masalah yang terus mendapat perhatian Indonesia dan RDTL, terutama semenjak RDTL resmi memisahkan diri dari Indonesia pada tahun 1999, menyusul hasil jajak pendapat rakyat Timor Timur yang memilih merdeka menjadi negara sendiri. Berdirinya RDTL sebagai negara baru tentangga Indonesia mengharuskan kedua negara menyepakati batas negara baik untuk wilayah darat, laut dan udara, dimana sebagai dasar penentuan perbatasan darat adalah Traktat/Treaty Tahun 1904 antara Belanda dengan Portugis (Direktorat Jendral Penanganan Perbatasan 2007).

Sejauh ini, landasan pengelolaan wilayah perbatasan kedua negara tidak mengacu pada selain peraturan yang telah ditetapkan secara internal oleh masing-masing negara. Selain itu, pengelolaan perbatasan jelas tidak dapat dipisahkan dengan aturan main internasional dan berbagai perjanjian yang telah disepakati oleh kedua pemerintahan. Dalam hal ini yang kemudian dikembangkan menjadi traktat 1904 tentang Convention for Settlement of Timor Boundary dan dokumen Mota Talas dan dokumen Oil Poli tahun 1915, sebagai peraturan pelaksanaan dalam pemasangan tugu batas wilayah darat di sepanjang perbatasan yang menjadi salah satu landasan penting dalam pengelolaan perbatasan RI RDTL.

Pemahaman nilai strategis wilayah perbatasan kemudian mendorong pemerintah dalam beberapa tahun terakhir ini untuk lebih serius memperhatikan wilayah yang selama ini seolah menjadi forgotten land. 
Sejumlah langkah telah dilakukan pemerintah Indonesia mengelolah keamanan perbatasan Indonesia dan Timor Leste (Puspitasari 2013). Pengelolaan keamanan di perbatasan dilakukan oleh pemerintah Indonesia secara unilateral maupun bilateral dengan adanya diplomasi perbatasan (Border Diplomacy) dengan pemerintah Timor Leste. Pemerintah membuat beberapa kebijakan mengenai pengelolaan keamanan di perbatasan seperti Pepres Nomor 78 Tahun 2005, UU Nomor 43 tentang Wilayah Negara, RPJMN 2004-2009 dan RPJMN 2010-2014. Sementara itu, diplomasi perbatasan dijalankan pemerintah Indonesia dengan membentuk Joint Border Committee (JBC) untuk melakukan serangkain pertemuan dengan pemerintah Timor Leste guna membahas perbatasan di kedua Negara, yang dimulai sejak tahun 2002. Namun demikian kebijakan mengenai kebijakan pengelolaan keamanan di perbatasan Indonesia- Timor Leste belum berjalan secara semestinya. Akibatnya, pengelolaan keamanan di perbatasan Indonesia dan Timor Leste tidak berjalan secara efektif.

Fenomena pelintas batas ilegal (illegal crosser border) lantas masih menjadi salah satu permasalahan yang potensial menggangu hubungan baik Indonesia dan RDTL. Para pelintas batas ilegal ini masuk melalui daerah perbatasan, baik itu pintu imigrasi atau akses resmi dan apa yang disebut sebagai "jalan-jalan tikus" yang tidak terkontrol, yang banyak terdapat di sepanjang garis perbatasan Indonesia dengan Timor Leste. Dari data intelijen TNI, terdapat total 42 jalan tikus di sepanjang 148,7 $\mathrm{km}$ perbatasan Indonesia-Timor Leste (Madu et al. 2010). Karakteristik perbatasan Indonesia dengan Timor Leste di wilayah Nusa Tenggara Timur (NTT) ikut memberi 'warna lain' terhadap fenomena pelintas batas ilegal antara kedua negara. Wilayah batas antara NTT dengan RDTL di Kabupaten Belu misalnya hanya dibatasi oleh sungai, namun tidak seperti umumnya sungai di wilayah Kalimantan, sungai di NTT cenderung kering saat musim kemarau sehingga mudah ditembus para pelintas batas tanpa melalui pemeriksaan imigrasi, bea cukai atau karantina. Sungai yang kering tersebut bahkan dapat dilalui dengan menggunakan motor ataupun mobil. Alhasil banyak warga negara Timor Leste yang dideportasi oleh pihak Imigrasi Atambua. Pada tahun 2015 misalnya, ada 77 orang Timor Leste yang dideportasi karena mereka masuk melalui jalan tikus (Imigrasi Atambua 2017).

Ada sembilan titik pemeriksaan sesuai nota kesepahaman 2003 antara Indonesia-Timor Leste 2003. Dari sembilan pos yang telah beroperasi, hanya tiga pos yang telah menggunakan standar perlintasan internasional atau menggunakan paspor. Sisanya menggunakan perlintasan tradisional yang menggunakan Pas Lintas Batas (PLB) sebagai pengganti paspor. Sembilan titik pemeriksaan itu adalah Tempat Pemeriksaan Imigrasi (TPI) Mota'ain, TPI Builalu, TPI Laktutus, Pos Turiskain di Kabupaten Belu, TPI Metamauk (Motamasin) di kabupaten Malaka, TPI Napan, Pos Wini, dan Pos Haumeni Ana di Kabupaten 
Timor Tengah Utara. Dari total sembilan titik pemeriksaaan, TPI Motaain merupakan yang paling ramai dan bagus (Imigrasi Atambua; 2017).

Meskipun berbagai upaya penyelesaian masalah perbatasan terus diupayakan oleh kedua pihak, fenomena pelintas batas ilegal masih menjadi persoalan yang perlu mendapat penanganan. Dari pihak Indonesia, langkah-langkah strategis penyelesaian masalah perbatasan serta pembangunan berbagai fasilitas terkait di wilayah perbatasan dengan Timor Leste adalah bagian dari upaya komprehensif menyelesaikan berbagai potensi masalah di wilayah perbatasan, termasuk di dalamnya adalah persoalan pelintas batas ilegal (illegal crosser border).

\section{Border Governance}

Perbatasan adalah ruang yang bersifat kompleks dimana terjadi interaksi sosial, ekonomi, kultural antara berbagai komunitas berbeda negara yang hidup di dalamnya. Oleh karena itu, pengelolaan perbatasan seharusnya bersifat terintegrasi dengan memperhatikan aspek-aspek lain diluar aspek keamanan. Pendekatan terintegrasi sebagaimana ciri border governance setidaknya sejalan dengan konstruksi berpikir yang dibangun oleh Brunet-Jailly (2005). Gagasan Brunet-Jailly (2005) terkait border governance bersifat multi-dimensi dengan mencakup antara lain aspek sosial, ekonomi, agama, linguistik, entitas dan budaya yang dianut oleh masyarakat setempat (Brunet-Jailly 2005).

Lebih spesifik, Brunet-Jailly (2005) menyatakan bahwa tata kelola perbatasan harus mengintegrasikan empat dimensi. Pertama, kekuatan pasar dan arus perdagangan (market forces and trade flows). Kedua, kebijakan berbagai tingkat pemerintahan di wilayah yang berbatasan (policy activities of multiple levels of governments on adjacent borders). Hal ini terkait hubungan horizontal antara lembaga pemerintah yang setara dan hubungan vertikal antara lembaga pemerintah dengan hierarki otoritas yang berbeda baik dari pusat hingga daerah. Ketiga, pengaruh politik tertentu dari masyarakat perbatasan (the particular political clout of borderland communities). Dimensi ini meliputi sejauh mana aktor-aktor lokal memberikan pengaruhnya dalam penentuan tata kelola perbatasan antara kedua negara. Pada konteks lokal ini, tata kelola perbatasan harus memperhatikan suara masyarakat setempat dan juga berbagai organisasi sosial masyarakat. Keempat, budaya khas masyarakat perbatasan (the specific cultures of borderland communities). Hal ini berkaitan dengan konteks lokal, yang mana suatu garis perbatasan biasanya memotong secara acak kelompok linguistik, adat, latar 
belakang sosial ekonomi, identitas budaya, dan latar belakang historis yang sama.

Berdasarkan kerangka teori yang dibangun oleh Brunet-Jailly (2005), maka dapat dikatakan bahwa dinamika kultural menjadi basis penting dalam kasus pelintas batas illegal di daerah Timor, mengingat bahwa etnik Dawan Indonesia maupun etnik Dawan Timor Leste memiliki kesamaan sejarah, asal usul, serta kesamaan sosial kultural termasuk di dalamnya adat istiadat, bahasa, dan agama. Teorisasi Brunet-Jailly (2005) dalam perspektif penulis dapat dikatakan sebagai cara dan pendekatan terintegrasi karena mencoba melihat persoalan perbatasan dari berbagai aspek yakni: (1) ekonomi dengan memperhatikan kekuatan pasar dan arus perdagangan; (2) kebijakan pemerintah secara internal dan eksternal; (3) faktor politik masyarakat di wilayah perbatasan; serta (4) budaya khas masyarakat di wilayah perbatasan. Aspek budaya menjadi perhatian khusus Brunet-Jailly (2005) mengingat hal tersebut dijadikan landasan dan falsafah hidup masyarakat adat yang bersifat borderless. Disamping itu, masyarakat adat yang memiliki beragam public properties dapat dijadikan sebagai potensi kebijakan dalam penanganan sejumlah persoalan di wilayah perbatasan Indonesia-Timor Leste.

Masih dalam pemahaman yang sama terhadap konsep cross border governance, tulisan Gualini (2003), mencoba melihat cara kerja cross border governance melalui pendekatan institusi baik secara vertikal (multi-level pemerintahan) maupun horisontal sebagaimana dalam kasus integrasi Eropa. Bahwa dalam konteks kontemporer, seiring dengan intensitas dan luasnya masyarakat transnasional (transnational communities), muncul beragam persoalan baik dalam aspek politik, ekonomi, sosial kultural, serta isu-isu lingkungan. Terkait persoalan aktivitas lintas batas (border activities), yang bersifat transnasional (transnational activities) seperti border crossing population atau transnational migration, perdagangan lintas batas, dalam hal ini bahkan dapat diasumsikan sebagai konsep lokal people mobility melewati batas-batas negara sebagaimana yang dilakukan etnik Dawan. Maka dari itu, perlu dilakukan pemikiran ulang (re-framing) tentang pendekatan perbatasan yang lebih terintegrasi, holistic, serta komprehensif. Yang dimaksud di sini adalah bahwa perbatasan sebagai batas statehood bukan sekedar basis fisik teritorial negara semata melainkan juga mencakup aspek lain, termasuk penduduk beserta identitas politik yang dimilikinya (the politics of identification). Ketika negara lalai dalam penanganan substansi publik, maka akan muncul beragam persoalan lintas batas seperti penyelundupan (smuggling), pasar gelap (black market), jalan tikus, pengelolaan tanah ulayat, serta berbagai persoalan lintas batas lainnya. Bagi negara, kondisi tersebut merupakan pelanggaran hukum tanpa pernah bertanya mengapa terjadi pelanggaran tersebut. 
Kajian tentang tata kelola perbatasan Indonesia dan Timor Leste dalam kaitan dengan posisi etnis Dawan akan beranjak dari konseptualisasi integrated border governance atau tata kelola perbatasan yang terintegrasi. Konsep ini dapat dioperasionalisasikan sebagai sebuah model tata kelola perbatasan yang merujuk pada: (1) penggunaan wewenang untuk mengatur, menata, dan membangun perbatasan yang melibatkan aktor negara dan non-negara dalam berbagai jenjang administrasi pusat, provinsi dan daerah; (2) pelibatan komunitas lokal yang hidup sepanjang perbatasan, yang dalam hal ini berperan bukan sebagai obyek melainkan sebagai partisipan aktif dalam tata kelola perbatasan; (3) pelibatan aktor dari berbagai jenjang administrasi vertikal dan horizontal untuk bekerja bersama dalam jaringan tata kelola yang didasarkan pada konsensus; (4) penempatan negara bukan lagi sebagai aktor utama melainkan salah satu aktor yang bekerja bersama aktor lain dalam sebuah jaringan tata kelola; (5) penempatan perbatasan bukan sebagai ruang fisik dan territorial politik, tetapi ruang interaksi manusia yang melibatkan dimensi lingkungan hidup, sosial, kultural, ekonomi dan politik; (6) pengelolaan perbatasan yang tidak hanya bertumpu pada pendekatan keamanan melainkan mengintegrasikan pendekatan politik pemerintah negara yang berbatasan, pendekatan kultural dimana komunitas lokal adalah aktor kunci, pendekatan pasar, dan kemakmuran seraya memperhatikan dinamika politik lokal di antara komunitas-komunitas yang hidup di dua atau lebih sisi perbatasan dari negara yang bertetangga; (7) penggunaan diplomasi perbatasan untuk mengembangkan kerja sama yang memfasilitasi pergerakan lintas batas demi tujuan keamanan, perdamaian dan kemakmuran masyarakat.

\section{Dinamika Persoalan yang Muncul Akibat Garis Perbatasan}

Pasca referendum tahun 1999, batas wilayah administratif antara Provinsi NTT dan Timor Timur berubah menjadi batas negara. Perubahan ini memunculkan persoalan tersendiri bagi sebagian besar masyarakat di wilayah berbatasan antara Indonesia dan Timor Leste, salah satunya terkait dengan batas wilayah tradisional (batas adat) yang dilewati oleh garis batas negara yang sedari awal merujuk pada perjanjian Belanda dan Portugis. Selain itu, terdapat pula persoalan terkait hubungan ekonomi dan perdagangan yang sudah terjalin sebelumnya. Salah satunya ditunjukkan oleh penduduk Oecusse yang berada di wilayah enclave, yang bergantung pada perdagangan lintas batas untuk suplai bahan-bahan pokok. Lebih lanjut, hadirnya batas negara telah berdampak pada perubahan geo-teritorial yang memisahkan ikatan-ikatan kultural, kekerabatan dan kekeluargaan yang dipegang kuat oleh masyarakat Etnik Dawan di Timor bagian barat. Akibatnya, hukum positif yang mengatur perbatasan mendefinisikan aktifitas lintas batas orang dan barang menjadi dua, yaitu legal dan 
ilegal. Hal ini menjadi persoalan kompleks karena pada dasarnya para pelintas batas melintasi batas negara untuk berbagai urusan. Mulai dari urusan keluarga, seperti kelahiran, kematian, ritual tradisional, pendidikan, kesehatan, perdagangan dan lain sebagainya (Taum 2015). Berikut, beberapa persoalan yang muncul di tengah masyarakat etnik Dawan hingga hari ini ketika hubungan-hubungan mereka terpisah dengan hadirnya batas negara.

\section{Persoalan Tapal Batas}

Persoalan yang paling menyolok dari hadirnya batas negara adalah persoalan penetapan garis batas kedua negara. Setidaknya ada tiga kabupaten di NTT yang dilintasi garis batas negara dan masih belum terselesaikan hingga hari ini. Titik perbatasan tersebut adalah Noel Besi di Kabupaten Kupang, Manusasi di Kabupaten Timor Tengah Utara (TTU) dan Memo di Kabupaten Belu. Di Kecamatan Bikomi Nilulat, Kabupaten TTU saja terdapat 6 (enam) titik perbatasan yang berpotensi menimbulkan konflik antar warga (Bere 2016). Sesungguhnya pemerintah Indonesia dan Timor Leste telah menyepakati titik kordinat dari batas kedua negara pada tahun 2002. Namun, hal ini menuai kritik, karena menurut Bupati TTU Raymundus Sau Fernandez, pemerintah daerah dan masyarakat adat setempat tidak dilibatkan dalam penentuan batas tersebut (Bere 2016). Terdapat ketidaksepahaman di antara masyarakat lokal jika garis perbatasan yang disepakati merujuk pada Traktat 1904.

Salah satu ketidaksepahaman tersebut menurut Kepala Pusat Pemetaan Batas Wilayah Bakosurtanal, Sobar Sutrisna (2007), disebabkan oleh faktor teknis dalam menginterpretasikan geografis antara toponomi (penamaan) pada kurun waktu traktat 1904 disepakati Belanda dan Portugis dengan kondisi rill hari ini. Traktat 1904 mendefinisikan batas wilayah kekuasaan Portugis dan Belanda di pulau Timor pada saat itu dengan menggunakan batas alam, yaitu sungai-sungai yang membelah pulau Timor di bagian barat dan timur. Dalam kurun waktu lebih dari satu dekade, sejak traktat itu ditandatangani tahun 1904, tentu telah terjadi berbagai perubahan dinamis pada sungai-sungai tersebut. Aktivitas alam, seperti hujan dan bencana alam misalnya secara potensial menyebabkan perubahan bentuk aliran sungai (Ibrahim 2006). Hal ini lantas memunculkan penolakan serta perebutan atas akses sumber daya alam yang antara lain didorong oleh klaim masyarakat setempat atas beberapa wilayah yang sekarang disengketakan dengan alasan sejarah, ekonomi, dan sosial budaya. Sebab sejarah pemisahan pulau Timor menjadi dua sebagaimana yang termaktub dalam traktat 1904 mengaburkan kesepakatan batas wilayah adat yang ada sebelumnya. Salah satu persoalan serius terkait penentuan batas negara antara Indonesia-Timor Leste dalam wilayah 
etnik Dawan yakni enam titik bermasalah yang terletak di Desa Manusasi, Kecamatan Miomafo Barat, hingga Nelu, Desa Sunsea, Kecamatan Naibenu, Timor Tengah Utara.

\section{Persoalan Lintas Batas dan "Jalan Tikus" sebagai Pilihan Rasional Warga}

Secara hukum internasional, kehadiran Pos Lintas Batas Negara (PLBN) adalah amanah Undang-Undang yang harus dilaksanakan dalam rangka menjaga ketertiban dan keteraturan lalu-lintas barang dan manusia. Namun dalam realitanya, tujuan tersebut kadang diabaikan demi suatu kepentingan terutama kepentingan ekonomi. Kuatnya intervensi aktor negara dalam hal ini Pasukan Pengaman Perbatasan (PAMTAS) dan unsur Kepolisian dalam praktiknya telah menganggu mobilitas barang dan manusia di Pos Lintas Batas Negara. Bahkan perilaku aparat keamanan dan unsur kepolisian telah dianggap sebagai momok bagi masyarakat di sekitar perbatasan. Sebelumnya, perlu dipahami bahwa kemerdekaan Timor Leste, secara ekonomi menguntungkan pengusaha lokal di NTT. Namun, peluang tersebut harus dibayar mahal dengan pungutan liar (pungli) petugas keamanan manakala mereka hendak memasok barang ke Timor Leste. Hasil wawancara penulis dengan beberapa sopir kontainer yang membawa barang masuk ke Timor Leste memperlihatkan bagaimana praktik Pungli yang dilakukan oleh aparat penjaga perbatasan.

UR (Wawancara tanggal 10 Mei 2018), seorang sopir truk tronton yang rutin melewati pos Lintas Batas Negara menyatakan: "Besarnya sogokan ke aparat keamanan dan kepolisian tergantung jumlah dan jenis barang. Khusus sembako misalnya, satu kontainer dihargai 5 juta dengan rincian 3 juta untuk PAMTAS dan 2 juta untuk pihak Kepolisian. Jika tidak membayar, maka mobil kita akan ditahan berjam-jam bahkan bisa berhari-hari atau bahkan dibongkar dan barang sengaja diturunkan. Biar aman dan lancar, terpaksa membayar saja bahkan sudah dianggap kewajiban oleh para pengusaha lokal untuk membayar". Lebih lanjut UR mengatakan jika sogokan tersebut merupakan hal rutin dengan besaran yang sudah baku, sehingga umumnya para sopir sudah mempersiapkan terlebih dahulu "amplop" yang akan diberikan. Besaran pungutan liar sebagaimana diungkapkan UR, dapat dilihat dari tabel di bawah: 


\begin{tabular}{|c|c|c|c|}
\hline No & Jenis Pungli & Besaran Pungli (Rp) & KETERANGAN \\
\hline 1 & $\begin{array}{l}\text { Truk Tronton } \\
\text { (pembawa } \\
\text { barang ekspor) }\end{array}$ & $\begin{array}{l}\text { 1. Brimob: } 400.000 \\
\text { 2. Polisi Militer: } \\
\text { 300.000 } \\
\text { 3, Kapospol: } 400.000 \\
\text { 4. Pamtas: } 300.000 \\
\text { 5. Intel Korem: } \\
\text { 300.000 } \\
\text { 6. Intel Kodim: } \\
\text { 150.000 } \\
\text { 7. Karantina: } \\
\text { 250.000 } \\
\text { 8. Imigrasi: 300.000 } \\
\text { 9. Bea Cukai: } \\
\text { 500.000 }\end{array}$ & $\begin{array}{l}\text { Total biaya pungli sudah } \\
\text { standar dan tidak ada } \\
\text { kompromi. Jika tidak, } \\
\text { maka mobil akan di } \\
\text { tahan berjam-jam, harus } \\
\text { membawa minuman } \\
\text { untuk petugas } \\
\text { keamanan di pos Lintas } \\
\text { Batas. }\end{array}$ \\
\hline 2 & $\begin{array}{l}\text { Masuk Pasar } \\
\text { Perbatasan } \\
\text { Indonesia }\end{array}$ & $\begin{array}{l}\text { PAMTAS: } \\
\text { 10.ooo/kepala } \\
\text { (belum termasuk } \\
\text { jumlah dan Jenis } \\
\text { Barang). } \\
\text { Imigrasi, Bea Cukai: } \\
\text { tergantung jumlah } \\
\text { dan jenis barang. }\end{array}$ & $\begin{array}{lr}\text { Dibayar } & \text { oleh } \\
\text { masyarakat Timor Leste. } \\
\text { Guna menghindari } \\
\text { pembayaran tersebut, } \\
\text { warga Timor Leste } \\
\text { melakukan kegiatan } \\
\text { belanja dengan sistem } \\
\text { perwakilan (mengutus } \\
\text { beberapa warga untuk } \\
\text { berbelanja dan yang } \\
\text { lainnya menunggu di } \\
\text { seberang). }\end{array}$ \\
\hline
\end{tabular}

Praktik pungli di PLBN bukan hal baru bagi para pengusaha lokal bahkan warga pribumi yang ingin menjual produk/barang atau sekedar membeli oleh-oleh ketika berkunjung ke sanak keluarga di seberang. Banyak kasus dan laporan warga terhadap praktek pungli yang dilakukan aparat keamanan namun tidak pernah direspon secara serius oleh pemerintah, seolah-olah praktek tersebut legal dan sah. Akibat praktek tersebut, tidak jarang masyarakat menggunakan logika berpikirnya sendiri. "Jalan tikus" menjadi satu alternatif yang dipilih 
masyarakat Dawan untuk dapat melakukan aktivitas lintas batas. Dari sisi hukum positif tindakan tersebut merupakan tidakan illegal. Bagi penulis, pilihan jalan tikus merupakan tindakan rasional ketika fenomena pungli di perbatasan juga sama-sama merupakan tindakan melanggar hukum positif.

Laporan Oxfam pada tahun 2008 menunjukkan kondisi keprihatinan yang mendalam dalam hal persoalan lintas batas negara di Indonesia dan Timor Leste. Laporan tersebut menceritakan bagaimana orangorang Oecusse yang ingin melintasi perbatasan dengan Indonesia memerlukan paspor yang membutuhkan biaya sekurang-kurangnya US\$ 25 dan memerlukan waktu satu minggu untuk diterbitkan, maupun visa yang mebutuhkan biaya sebesar US\$ 35 yang mana keduanya hanya tersedia di Dili. Hal ini berarti bahwa untuk mendapatkan akses lintas batas yang resmi ke desa-desa terdekat untuk keperluan keluarga maupun upacara adat, orang-orang Oecusse memerlukan sebuah perjalanan yang mahal dan memakan waktu ke Dili terlebih dahulu (Hulthouse and Grenfel; 2008). Hal ini diperparah karena pemerintah Indonesia tidak memberikan visa multi-entry (masuk berkali-kali). Kendatipun visa dua kali jalan tersedia, persyaratan bahwa kedua perjalanan tersebut harus dilakukan dalam kurun waktu satu minggu agaknya meniadakan kelebihan apapun dibanding dengan visa singleentry (sekali masuk). Sementara itu, orang-orang Indonesia yang ingin masuk ke Oecusse dilayani agak lebih baik dengan layanan visa-onarrival (visa pada saat kedatangan) di pos-pos perbatasan di Bobometo (di sub-distrik Oesilo) dan Sakato (titik bagian timur di mana perbatasan bertemu dengan laut). Namun, biaya US\$30 tetap memberatkan sebagian besar masyarakat (Hulthouse and Grenfel; 2008).

Besarnya biaya untuk melintasi batas negara lantas memunculkan persoalan-persoalan terkait, seperti penyelendupan. Beberapa kasus yang sempat tercatat terkait penyelundupan melalui "jalan tikus" di wilayah perbatasan Kabupaten TTU dan Distrik Oecussie pada 2014 antara lain penyelundupan BBM, yakni bensin 1725 liter, solar 665 liter, minyak tanah 790 liter; penyelundupan 2 ekor ternak 2; penyelundupan sembako; dan penyelundupan berberapa kebutuhan rumah tangga lain dengan jumlah yang bervariasi. Praktik-praktik penyelundupan yang sempat terungkap dapat dikatakan hanyalah puncak dari sebuah gunung es, yang mana kasus-kasus lain yang belum terungkap berpotensi menyebabkan kerugian yang lebih besar. Penyelundupan marak karena tingginya selisih harga barang di kedua negara. Di Timor Leste, harga seliter bensin mencapai 2 dollar AS atau empat kali lipat harga bensin di Atambua. Selain mahal, pasokannya tidak lancar. Begitu pula harga sayur yang umumnya lebih mahal dua hingga tiga kali lipat. Hal itu mendorong banyak warga negara tetangga lebih senang membeli barang yang dipasok dari wilayah Indonesia (Herin dan Tambunan; 2016). 
Dengan kondisi ini, tidak jarang pilihan terhadap jalan tikus adalah cara dan pola rasional bagi mereka untuk menghindari praktek pungli oleh aparat keamanan (Herin dan Tambunan; 2016).

\section{Pembangunan Berbasis Masyarakat dan Common Prosperity}

Pada awal tahun 2017, Presiden Joko Widodo meresmikan beberapa Pos Lintas Batas Negera (PLBN) termasuk di wilayah perbatasan IndonesiaTimor Leste, tepatnya PLBN Mota Ain di Kabupaten Belu, dan PLBN Mota Masin di Kabupaten Malaka, serta PLBN Wini di Kabupaten TTU. Tidak hanya itu, sebelumnya Presiden Jokowi juga menetapkan RPJMN 2015-2019. Dalam RPJMN tersebut, pembangunan kawasan perbatasan menjadi salah satu prioritas, terutama pembangunan ekonomi dan infrastruktur. Menteri PDTT Marfan Jaffar mengatakan bahwa pihaknya akan memprioritaskan pembangunan 1.138 desa tertinggal yang berada di jalur perbatasan lintas Negara. Pernyataan Menteri PDTT tersebut didukung dengan pernyataan Menko Pembangunan Manusia dan Kebudayaan Puan Maharani yang menyatakan bahwa sebanyak 5000 Puskesmas akan dibangun di perbatasan. Lebih lanjut, Menteri Puan mengatakan bahwa terdapat kesenjangan ekonomi dan kesejahteraan antara Indonesia dan negara tetangga. Oleh karena itu, setiap lembaga dan kementerian diharapkan bisa bekerja sama dan bersinergi dalam mewujudkan dan memaknai frontier (baris depan) negara. Bila tidak ditangani dengan baik, persoalan perbatasan negara akan tetap menjadi pekerjaan rumah yang besar bagi pemerintahan siapapun. Perlu diketahui bahwa hasil evaluasi dari implementasi program anggaran perbatasan tahun 2014 yang lalu hanya terealisasi 17 persen saja. Tahun 2015, total anggaran untuk wilayah perbatasan sebesar 15,9 triliun. Ini berarti, dari sisi politik anggaran, pemerintah sangat peduli pada penanganan dan pembangunan di wilayah perbatasan. Namun, jika fokus pembangunan hanya pada aspek fisik semata tanpa memerhatikan kondisi sosial ekonomi masyarakat, maka pembangunan justru menciptakan persoalan baru. Oleh karena itu, perlu adanya perpaduan secara linier antara program fisik dan non-fisik terutama menyangkut kepentingan penduduk di wilayah perbatasan.

Satu pendekatan dalam tata kelola perbatasan adalah pembangunan kesejahteraan dengan sasaran mencapai kemakmuran bersama (common prosperity). Dalam pendekatan ini, tata kelola perbatasan perlu melibatkan komunitas Dawan melalui pembangunan berbasis masyarakat. Perubahan pendekatan ini diperlukan mengingat pendekatan kedaulatan yang selama ini dilakukan di wilayah perbatasan menuai kritik masyarakat setempat akibat salah kelola yang dilakukan pemerintah. Dalam konteks ini, kedaulatan tidak sekedar ekspansi kekuatan militer untuk menjaga wilayah negara dari ancaman luar, namun jauh lebih penting bagaimana masyarakat di wilayah perbatasan 
memiliki akses untuk merasakan kehadiran negara melalui pendekatan kesejahteraan (prosperity approach). Kedaulatan teritorial dalam konteks militer seakan mulai bergeser kepada konsep kedaulatan yang lebih menjawab kebutuhan masyarakat yakni kedaulatan pangan, kedaulatan kesehatan, kedaulatan pendidikan, kedaulatan infrastruktur, dan lain-lain. Dalam mewujudkan makna kedaulatan secara lebih luas tersebut, maka peran masyarakat di wilayah perbatasan menjadi penting sebagai obyek sekaligus subyek dari pembangunan itu sendiri. Salah satunya dengan menjadikan aspirasi masyarakat yang disampaikan melalui berbagai mekanisme forum pembangunan sebagai referensi pemerintah dalam pengambilan keputusan. Tidak hanya itu, masyarakat juga mengritik pola penyelesaian persoalan perbatasan yang selama ini menanti intervensi pusat sehingga menyebabkan pengambilan keputusan cenderung lama. Dalam hal ini perlu adanya pembagian wewenang dalam pembuatan kebijakan antara pemerintah pusat dan daerah. Pembagian wewenang dapat dilakukan dengan berdasarakan pada tingkat urgensi masalah perbatasan yang terjadi di daerah. Misalnya, kebijakan sektoral terkait kebutuhan air bersih, pendidikan, pelayanan kesehatan sebaiknya diserahkan ke daerah. Dalam pembagian wewenang ini, konsep local wisdom mampu dilaksanakan secara optimal karena masyarakat setempat turut menentukan arah kebijakan pembangunan itu sendiri.

Untuk itu, cara pandang wilayah perbatasan sebagai area merah (red area) dengan berbagai permasalahan perlu untuk dihapuskan. Cara pandang negatif tersebut pada dasarnya muncul sebagai akibat adanya terminologi hard-border regime yang menjadikan wilayah perbatasan sebagai wilayah yang perlu dikawal/dijaga secara ketat oleh aparat militer bersenjata. Kondisi ini telah menghilangkan peluang aspek lain yang seharusnya bisa dieksplorasi untuk meningkatkan kesejahteraan masyarakat. Pembangunan wilayah perbatasan dalam konsep kekinian seharusnya menjadikan wilayah perbatasan terutama PLBN sebagai pusat pertumbuhan ekonomi yang dapat dimanfaatkan bersama oleh kedua wilayah negara. Konsep pembangunan ini pada dasarnya telah dicanangkan oleh Presiden joko Widodo saat mengresmikan PLBN di Entikong. Presiden Joko Widodo (Humas Setkab RI; 2016) menyatakan bahwa: "Pembangunan wilayah perbatasan tidaklah cukup sebatas bangunan fisik semata". Oleh karena itu, Presiden Jokowi lantas menginstruksikan untuk segera menggerakkan roda perekonomian di kawasan tersebut, salah satunya dengan membangun pasar untuk mendorong pertumbuhan ekonomi masyarakat setempat.

Secara tersirat, penyataan Presiden Jokowi tersebut berkaitan dengan bagaimana menciptakan suatu kondisi kondusif di sekitar PLBN sehingga kawasan tersebut dapat memberikan ruang sekaligus peluang bagi pengembangan ekonomi lokal demi peningkatan kesejateraan masyarakat sekitar. Dalam hal ini, himbauan tersebut pelu untuk segera 
ditindaklanjuti dengan langkah-langkah konkrit seperti perumusan konsep pembangunan ekonomi lokal (local economic development) berdasarkan potensi yang ada. Tidak hanya itu, pendekatan pembangunan pun segera diubah dari hard-border menjadi soft-border regime. Peluang lain yang dapat ditindaklanjuti dalam mewujudkan common prosperity adalah kerja sama lintas batas dengan melihat potensi sektoral yang dapat dimanfaatkan bersama oleh masyarakat kedua negara misalnya sektor pendidikan, kesehatan, serta kebutuhan dasar lainnya seperti air bersih, listrik, dan potensi ekonomi lokal yang dibutuhkan masyarakat. Untuk mewujudkan konsep common prosperity tersebut maka pelibatan berbagai stakeholders perlu dilakukan agar setiap komponen mengetahui tugas dan tanggung jawabnya masing-masing.

Pemerintah saat ini sedang giat melakukan pembangunan wilayah perbatasan terutama membangun infrastruktur dalam rangka memaknai konsep frontier guna menjaga nama, harkat dan martabat di mata internasional, utamanya egara tetangga. Kebijakan tersebut tidak keliru mengingat pelaksanaan pembangunan dilakukan secara bertahap berdasarkan skala prioritas yang ditetapkan. Namun di satu sisi harus diakui bahwa pembangunan yang langsung menyentuh kepentingan masyarakat perbatasan masih sangat minim, terutama dalam kaitannya dengan dimensi sosial kultural masyarakat. Tidak heran ketika melihat bangunan PLBN yang megah tidak selaras dengan realitas sosial masyarakat yang bermukim di wilayah perbatasan. Tingkat kemiskinan masyarakat masih tinggi, pelayanan kesehatan masih jauh dari harapan, serta kondisi ekonomi masyarakat masih powerless. Salah satu strategi yang dapat digunakan untuk mengubah kondisi tersebut adalah dengan menciptakan kerja sama sektoral yang diinisiasi dan difasilitasi oleh pemerintah untuk menjawabi kebutuhan masyarakat setempat, utamanya etnik Dawan. Kerja sama sektoral yang penulis maksud di sini mencakup kerja sama di bidang kesehatan, pendidikan, ekonomi, air bersih dan sanitasi, hingga pengembangan pasar tradisional. Dalam hal ini, komunitas-komunitas etnik Dawan yang terpisah dalam dua negara harus dilibatkan dalam perencanaan, pelaksanaan, dan pengawasan dari proyek kerja sama yang dilakukan.

Untuk mendukung kerja sama sektoral dan pembangunan berbasis masyarakat tersebut, tata kelola dan pengawasan perbatasan kedua negara harus bersifat cair, longgar, dan tidak terlalu formal. Sifat cair memungkinkan adanya interaksi dan kerja sama antar negara, baik kerja sama bilateral maupun kerja sama bidang sektoral sesuai kebutuhan riil di lapangan. Hubungan bilateral yang harmonis dibutuhkan dalam mewujudkan tata kelola berbasis connectivity dan common prosperity. Terkait hal ini, Rondinelli (dalam Muta'ali; 2014) mengidentifikasi tujuh konektivitas (spatial lingkages) yang dapat dijadikan sebagai dasar struktur ruang wilayah yaitu: (1) keterkaitan fisik /jaringan transportasi; 
(2) keterkaitan ekonomi; (3) keterkaitan pergerakan penduduk/ migrasi; (4) keterkaitan teknologi; (5) keterkaitan sosial; (6) keterkaitan pelayanan sosial; (7) keterkaitan administrasi, politik dan kelembagaan. Dengan adanya keterkaitan spasial ini, penduduk yang tinggal di wilayah perbatasan memiliki aksesibilitas terhadap berbagai pelayanan, fasilitas, infrastruktur, dan aktifitas ekonomi yang terjadi di antara dua wilayah negara yang berdekatan. Konektifitas ini pula yang menjadi inti dari rencana struktur ruang yang di dalamnya meliputi konektivitas vertical intra region atau keterkaitan antar jenjang hirarki dalam satu wilayah dan konektivitas horizontal inter region atau keterkaitan antar pusatpusat pertumbuhan dan hubungan daerah terpencil dan tertinggal. Kedua bentuk konektivitas dibutuhkan dalam mewujudkan integrasi wilayah yang komprehensif. Dalam rangka mewujudkan konektivitas di wilayah dan komunitas etnik Dawan, maka salah satu sifat cair yang saat ini menjadi modal sosial (social capital) bagi masyarakat kedua wilayah adalah interaksi sosial kultural yang dilandasi semangat kekeluargaan. Interaksi sosial ini tampak setiap hari pada arus migrasi lokal yang dilakukan dalam beragam kepentingan misalnya urusan adat istiadat, kematian, beternak dan berkebun, hingga kunjungan keluarga.

Dalam konteks ekonomi, pola hubungan penduduk oleh Martinez (1994) dikategorikan dalam "integrated border-land" yang didalamnya hubungan antar masyarakat bersifat stabil disertai dengan pelibatan mereka dalam berbagai kegiatan perekonomian yang saling menguntungkan serta kegiatan adat-istiadat yang berlangsung secara damai. Dalam bidang perekonomian, ketergantungan Timor Leste terhadap Indonesia sebesar $70 \%$. Sebaliknya, Indonesia juga bergantung pada impor dari Timor Leste dalam memenuhi beberapa kebutuhan misalnya peternakan, hasil bumi, serta beberapa kebutuhan lainnya. Sementara itu, sifat cair dalam aspek politik dapat diwujudkan dengan kesediaan menjalin dialog dan mengutamakan negosiasi ketimbang kekerasan militer ataupun konflik antar warga. Kondisi ini pula yang diharapkan oleh Pemerintah Timor Leste. Mantan Presiden Timor Leste Jose Ramos Horta (2014) pernah menyatakan secara tegas bahwa:

\footnotetext{
“Timor Leste tidak akan membentuk angkatan bersenjata yang kuat, kekuatan kami tidak sebanding dengan kekuatan Indonesia. Yang kami usulkan adalah menciptakan konsep Peace Island di seluruh pulau Timor, dan dengan modal tersebut kita bisa membangun kedamaian dan kerja sama yang lebih maju di tanah Timor antara Indonesia dan Timor Leste".
}

Dalam hal ini, pemerintah Timor Leste menyadari bahwa jika terjadi konflik dengan Indonesia, maka perekonomian masyarakat Timor Leste akan lumpuh dan kondisi ini sangat merugikan mereka. Realita hubungan penduduk yang tinggal di wilayah perbatasan Indonesia dan 
Timor Leste sangat mendukung perwujudan konsep integrated borderland mengingat bahwa pola hubungan mereka relatif stabil. Masyarakat di sekitar perbatasan juga terlibat dalam berbagai kegiatan perekonomian yang saling menguntungkan bahkan merupakan suatu kesatuan dalam sistem ekonomi tradisional.

Sementara itu, kerja sama sektoral yang dapat dikembangkan di sepanjang garis perbatasan mencakup berbagai bidang, salah satunya pembangunan sarana air bersih, infrastruktur pendidikan, maupun infrastruktur kesehatan seperti puskesmas. Sarana pendidikan menjadi penting bagi warga Timor Leste agar dapat bersekolah di sekolah Indonesia mengingat infrastruktur pendidikan di wilayah Oecussie yang masih minim. Masyarakat etnik Dawan perlu untuk menempuh jarak yang cukup jauh untuk bersekolah di ibukota Distrik. Argumentasi ini didasari pertimbangan empiris bahwa seolah-olah status kewarganegaraan mempersulit hubungan kerja sama sektoral ini. Akibatnya, masing-masing negara menjaga jarak satu sama lain hingga berdampak pada kesulitan mengakses kebutuhan dasar yang sejatinya diselesaikan melalui kerja sama sektoral.

Yang menjadi tantangan saat ini adalah belum adanya konsep yang jelas dari kedua negara dalam memaknai konsep konektivitas maupun common prosperity untuk menjawab persoalan masyarakat di wilayah perbatasan. Dalam hal regulasi misalnya, belum ada ruang kerja sama dalam bidang pendidikan maupun kesehatan yang memungkinkan masyarakat Timor Leste untuk mengakses pendidikan dan pelayanan kesehatan di wilayah Indonesia. Pihak Indonesia sejatinya telah membangun sekolah internasional di dekat garis perbatasan. Namun, sekolah ini cenderung sepi dan memiliki keterbatasan jumlah murid. Padahal, akses masyarakat Timor Leste terhadap fasilitas pendidikan dan kesehatan di wilayahnya masih sangat jauh. Realita inilah yang perlu untuk ditindak lanjuti oleh pemerintah kedua negara. Tidak hanya itu, sarana perhubungan kedua negara juga nyaris lumpuh akibat buruknya infrastruktur jalan dan minimnya sarana transportasi yang menghubungkan kedua wilayah negara, terutama di sepanjang perbatasan Timor Tengah Utara dan distrik Oecussie. Hal ini menjadi tantangan tersendiri karena pada dasarnya keterbukaan dan kelancaran akses antara kedua negara dapat memberikan multiplier-effect di berbagai aspek yang berguna bagi peningkatan kesejahteraan masyarakat kedua negara. Keterbukaan dan kelancaran akses juga secara tidak langsung membantu persiapan Timor Leste untuk mendukung implementasi konsep ASEAN Connectivity terlepas dari fakta bahwa hingga saat ini Timor Leste belum menjadi anggota tetap ASEAN. 


\section{Kesimpulan}

Peningkatan hubungan cross-boundary dan transnasional membutuhkan respon negara dalam mengelola pergerakan orang, barang dan jasa lintas batas di wilayah perbatasan negara bangsa. Dalam hal ini, kebijakan tata kelola perbatasan menjadi instrumen penting dalam mengatur sekaligus memanfaatkan proses-proses transborder yang terjadi di wilayah perbatasan. Dalam konteks ini, kebijakan tata kelola perbatasan sering kali mengabaikan variabel identitas kultural. Namun, hal ini justru menghasilkan respons sebaliknya yakni penggunaan identitas kultural untuk menantang konsepsi dan kebijakan dominan negara dalam tata kelola perbatasan. Salah satunya ditunjukkan dengan fenomena "jalan tikus" dan jaringan interaksi lintas batas lain yang disebut illegal oleh negara. Dengan menolak melaporkan pergerakan mereka ke pos-pos lintas batas, orang-orang Dawan menolak klaim tunggal terhadap ruang perbatasan sebagai ruang pertahanan keamanan dan ruang ekonomi. Bagi mereka ruang perbatasan adalah ruang interaksi sosial dan kultural yang mana identitas sebagai orang Timor Dawan menjadi dasar utamanya. Kehadiran Jalan tikus dan kunjungan-kunjungan lintas batas tak resmi merupakan bentuk tindakan untuk mempertahankan klaim dan akses mereka atas ruang perbatasan.

Setidaknya ada tiga kesimpulan teoritis yang dapat diambil dari fenomena tersebut. Pertama, sementara megara menempatkan perbatasan sebagai ruang manifestasi kedaulatan politik dan ekonomi, komunitas-komunitas masyarakat adat di perbatasan menempatkan perbatasan sebagai ruang interaksi sosial dan kultural. Dalam hal ini perlu dipahami bahwa pertukaran ekonomi memang terjadi, tetapi hanya sebagai bagian dari hubungan sosial kultural yang berbasis pada ikatan genealogis, etnisitas, dan kesamaan linguistik. Kedua, cara pandang lokal ini melahirkan konsekuensi lain yakni sikap mengabaikan kebijakan dan simbol-simbol kedaulatan territorial negara seperti tanda perbatasan, pos lintas batas, maupun instrumen perbatasan lainnya. Kehadiran simbol-simbol negara dalam bentuk pos lintas batas dan pasukan penjaga perbatasan bahkan dilihat oleh komunitas Dawan sebagai bentuk penindasan. Negara dianggap sebagai institusi yang "menyusahkan" kehidupan mereka dan menghambat interaksi lintas batas. Dengan kata lain, cara pandang komunitas lokal kontras dengan klaim negara bahwa perbatasan harus dijaga demi perlindungan dan keamanan warga dan dikelola demi kemakmuran warga. Hal ini diperparah dengan tindak korupsi yang kerap terjadi di wilayah perbatasan dengan adanya pungutan-pungutan liar yang justru menciptakan persepsi dalam komunitas lokal bahwa negara adalah sumber ketidakamanan mereka secara fisik dan ekonomi.

Ketiga, Masyarakat Dawan sejatinya memaknai wilayah perbatasan hanya sebatas wilayah adat. Batas wilayah adat tersebut lahir dari 
kesepakatan-kesepakatan adat yang senantiasa merujuk pada transformasi nilai dan harmonisasi. Transformasi nilai merujuk pada pemaknaan alam sebagai ruang hidup yang di dalamnya tata nilai dan tradisi itu lahir dan diwariskan secara turun temurun. Sementara itu, harmonisasi berkaitan dengan aspek kesejahteraan seluruh masyarakat di dalamnya. Bagi masyarakat Dawan, keterpisahan secara teritorial bukanlah hasil dari dinamika internal melainkan dampak dari luar dalam bingkai kepentingan rezim yang berkuasa. Kekuatan nilai-nilai tradisi lantas menjadi benteng terakhir bagi masyarakat Dawan dalam mendefinisikan dan menerjemahkan perbatasan sebagai ruang hidup mereka, yakni ruang dimana segala bentuk interaksi terbangun dari pengalaman-pengalaman mereka memaknai dan memperlakukan alam. Bukti bahwa interaksi antar masyarakat Dawan masih berlangsung hingga hari ini menjadi poin penting untuk mempertimbangkan adat sebagai bagian dari pendekatan kultural dalam tata kelola wilayah perbatasan antara Indonesia dan Timor Leste.

Dalam kebijakan tata kelola perbatasan yang terintegrasi, pendekatan budaya harus menjadi salah satu komponen utama berkaitan dengan pendekatan lainnya. Jika Brunet-Jailly (2005) menempatkan empat dimensi kebijakan secara sejajar, pendekatan budaya dalam kebijakan tata kelola perbatasan menjadi prinsip yang menjiwai kebijakan keamanan, politik lokal dan kebijakan ekonomi dalam tata kelola perbatasan. Dalam kaitan dengan keamanan, pendekatan budaya menempatkan keamanan kultural yakni keamanan komunitas, identitas budaya yang mereka miliki, serta keberlangsungan relasi sosio-kultural lintas batas sebagai prioritas kebijakan keamanan. Berbeda dengan keamanan militer yang menempatkan interaksi sosio-kultural lintas batas sebagai sesuatu yang mengancam keamanan teritorial, keamanan kultural menempatkan preservasi identitas budaya dan interaksi sosiokultural lintas batas sebagai elemen yang memperkuat keamanan hidup komunitas-komunitas di wilayah perbatasan. Dalam pengertian ini, interaksi lintas batas yang berbasis tradisi seperti ritual adat yang berkaitan dengan perkawinan, penghormatan kepada alam, tradisi komunitas dalam penyelesaian konflik, ritual kepercayaan lokal tidak ditempatkan sebagai ancaman dan gangguan keamanan nasional yang berbasis territorial. Preservasi kultural dan interaksi sosial lintas batas justru ditempatkan sebagai elemen esensial dalam tata kelola wilayah perbatasan karena berfungsi memelihara keseimbangan, stabilitas, dan perdamaian sosial di sepanjang perbatasan.

Konsekuensi praktis dari kajian ini adalah bahwa kebijakan tata kelola perbatasan harus keluar dari dominasi pendekatan keamanan ekonomi ke pendekatan terintegrasi. Dalam pendekatan terintegrasi, variable identitas kultural harus mendapat tempat sentral. Kajian ini mengusulkan konsep ruang sosial kultural lintas batas (trans-border social and cultural space) sebagai elemen penting dalam tata kelola 
perbatasan yang terintegrasi. Ruang sosial kultural lintas batas didasarkan pada gagasan sebagai berikut. Pertama, wilayah perbatasan diperlakukan bukan hanya sebagai wilayah territorial politik dan ekonomi, tetapi ruang pertemuan sosial antar warga kedua negara. Sebagai ruang sosial, model pengawasan tidak terlalu kaku dan ketat, tetapi lebih longgar dan disesuaikan dengan situasi yang dihadapi. Kedua, institusi-institusi lokal yang menjadi bagian dari properti publik difungsikan bersama dengan institusi-institusi negara berdasarkan prinsip tata kelola berjenjang. Dalam model ini, wewenang dan sumber daya finansial dalam penanganan perbatasan dibagi antara lembaga pemerintah dan lembaga masyarakat di tingkat lokal. Lembaga-lembaga masyarakat adat lokal juga diberi wewenang dan difungsikan untuk menangani kasus-kasus keamanan lokal yang melibatkan anggota komunitas berbeda warga negara. Ketiga, negara mendorong, memperkuat dan melegalkan fungsi institusi-institusi lokal, baik dalam bentuk norma, hukum adat, tradisi, dan organisasi dalam menangani isu-isu perbatasan yang muncul dari proses interaksi sosial dan kultural yang melibatkan masyarakat lokal di wilayah perbatasan.

\section{Referensi}

\section{Buku}

Bellwood, Peter, 1985. Prehistory of the Indo-MalayanArchipelago. Canberra: ANU Press.

Direktorat Jenderal Penanganan Wilayah Perbatasan Maritim RI, 2007. RDTL dalam rangka menjaga Keutuhan NKRI.

Gualini, Enrico, 2003. Cross Border Governance: Inventing Regions in a Trans-National Multi-Level Polity.

Held, David, et al., 1999, Global Transformations: Politics, Economics and Culture. Stamford: Stamford University Press.

Madu, Ludiro, et al., 2010. Mengelola Perbatasan Indonesia di Dunia Tanpa Batas. Yogyakarta: Graha Ilmu.

Martinez, Oscar, 1994. 'The Dynamics of Border Integration: New Approaches to Border Analysis", dalam Global Boundaries. London: Routledge.

Tylor, E. B., 1924. Primitive Culture. New York, NY: Brentano's.

\section{Jurnal dan Laporan Resmi}

Holthouse, Kym, dan Damian Grenfell. 2008. "Social and Economic development in Oecussie, Timor Leste". Laporan Oxfam Australia dan Globalism Institute. Melbourne: RMIT University Melbourne.

Brunet-Jailly, E., 2005. Theorizing borders: An interdisciplinary perspective. Geopolitics, 1O(4), pp.633-649. 
Muta'ali., 2014. Studi Kasus: Kasus Perbatasan NTT. Pusat Kajian Permukiman, Transmigrasi dan Perbatasan (Puspertrantas), Fakultas Geografi Universitas Gajah Mada.

Panizzon, M., 2011. Migration and trade: prospects for bilateralism in the face of skill-selective mobility laws. Melbourne Journal of International Law, 12, p.1-46.

Puspitasari, Yeni. 2013. Upaya Indonesia Dalam Menangani Masalah Keamanan Perbatasan Dengan Timor Leste Pada Periode 20022012. Skripsi. Jakarta: Departemen Hubungan Internasional Fakultas Ilmu Sosial dan Ilmu Politik UIN Syarif Hidayatullah.

Ketetapan MPR No. V/MPR/1999 tentang Pencabutan Ketetapan MPR No. IV/1978 tentang Integrasi Timor Timur.

\section{Artikel Koran}

Bere, Sigiranus Marutho, 2014. "Titik Perbatasan RI-Timor Leste Rawan Konflik", Kompas, 17 September [Online]. Dalam: http://regional.kompas.com/read/2014/09/17/08143221/6.Titik.di.Perbatasa n.RI-Timor.Leste.Rawan.Konflik [Diakses 24 Mei 2018].

Bere, Sigiranus Marutho, 2016. "6 Titik di Perbatasan RI dan Timor Leste Berpotensi Konflik”, Kompas, 24 September [Online]. Dalam: http://nasional.kompas.com/read/2016/09/24/17592861/6.titik.di.per batasan.ri.dan.timor.leste.berpotensi.picu.konflik [Diakses 24 Mei 2018].

Herin, Frans P., dan Irma Tambunan, 2016. "Para Pelintas Gelap itu Bebas Lewati Perbatasan”. Harian Kompas, 27 Oktober.

Humas Setkab Rl, 2016. Resmikan Wajah Baru PLBN Entikong, Presiden Jokowi: Nyatanya kita bisa kan? [Online]. Dalam: http://setkab.go.id/resmikan-wajah-baru-plbn-entikong-presiden-jokowinyatanya-kita-bisa-kan/ [Diakses 24 Mei 2018].

Ibrahim, Gibran Maulana, 2016. "Masalah Batas Darat dengan Timor Leste Belum Selesai, RI Tawarkan Solusi”, Detik News, 11 November [Online]. Dalam: https://news.detik.com/berita/d-3343373/masalah-batasdarat-dengan-timor-leste-belum-selesai-ri-tawarkan-solusi [Diakses 24 Mei 2018].

Kantor Imigrasi Atambua, 2017. Lagi - lagi !!! Kantor Imigrasi Atambua tangkap WN Timor Leste [Online]. Dalam: http://www.kanimatambua.com/index.php?me=detailberita\&mk=Berita\&kdd e=37 [Diakses 24 Mei 2018].

Kantor Imigrasi Atambua, 2017. Kendala Imigrasi Atambua: "Sense of Security" Pemda dan Dokumen Kependudukan [Online]. Dalam: http://www.imigrasi.go.id/index.php/berita/berita-utama/423kendala-imigrasi-atambua-sense-of-security-pemda-dandokumen-kependudukan [Diakses 24 Mei 2018].

Taum, Yoseph Yapi., 2015. Suku Dawan Nusa Tenggara Timur [Online]. Dalam: $\quad$ http://www.wacana.co/2015/08/suku-dawan-nusa-tenggaratimur.html [Diakses 13April 2018]. 